\title{
Polyglot Humanism in Germany circa 1520 as Luther's Milieu and FRANZ Matrix: The Evidence of the "Rectorate Page" of Crotus Rubeanus ${ }^{1}$ \\ POSSET
}

Résumé : L'humanisme polyglotte de la première partie du XVIe siècle constitue le milieu de Martin Luther et les conditions formatrices de sa théologie biblique. Ce contexte est illustré de manière succincte par un document connu comme "la page du rectorat de Crotus Rubeanus », qui date du mois de mai 1521. Ce document commémore l'achèvement du terme de Crotus en tant que recteur de l'université d'Erfurt. Dix-sept humanistes polyglottes s'y trouvent représentés, dont Luther.

\section{Introduction}

"No humanism, no Reformation" sums up the seminal essay of Bernd Moeller on "The German Humanists and the Beginnings of the Reformation" of almost half a century ago (first published in 1959). ${ }^{2}$ "No monasticism, no Reformation" is a more recent slogan (1997), which appeared in a study on monks in the Reformation in Hessen, Germany. ${ }^{3}$ Both ring true. Yet the interconnectedness of "humanism," "monasticism" and "Reformation" is a topic not fully explored in Reformation research, and a further "ism" needs to enter the picture, namely polyglotism as a distinctive concern among German intellectuals early in the sixteenth century — a phenomenon shared by monastic and non-monastic scholars alike. Polyglotism was an essential element of a renewed theology and may be the key to the understanding of the Reformer Martin Luther and of the emblems and inscriptions in the various languages on the rectorate page of Rector Crotus Rubeanus (c.14801545) of the University of Erfurt. This page will be considered here as evidence for Luther's association with humanism. The parchment page itself was created on the occasion of the conclusion of Crotus's time in office as 
rector of the university in May 1521. It is part of the matriculation records (Immakulationsbuch), which include a short report by Rector Crotus and the names of students of the winter semester of 1520-21. The page itself measures $29.5 \times 21.4$ centimeters. ${ }^{4}$ On it seventeen polyglot humanists are represented, including Luther.

With regard to my approach here, Lewis W. Spitz's works on humanism and the Reformation paved the way. ${ }^{5}$ Helmar Junghans's "premiere study" 6 of the young Augustinian Friar Martin Luther (1483-1546) focused on Luther's connections to a linguistically orientated humanism, and with subsequent studies Junghans provided significant insights into the humanistic milieu in which Luther came of age. ${ }^{7}$ Leif Grane's Martinus Noster (1994) pursued the idea and properly placed Luther in the context of the humanist movement, which he labeled "the German Reform movement." 8 The present study seeks to continue on this road, interpreting Luther within German humanism and elucidating these connections. Special attention will be given to the role of monasticism within this intellectual environment.

The notion of "reformation" itself is open to several understandings. ${ }^{9}$ Yet "Reformation" appears to be the best term available to designate the period of the early sixteenth century. The Latin reformatio was for a long time a monastic and spiritual concept imbued with the undertone of Romans 12:2 in the Vulgate version (reformamini, "reform yourselves"). The fifteenth century was a time of great reform efforts, which were inspired by this biblical concept. ${ }^{10}$ Without the monks and friars, who were accustomed to a literary culture, and who had opened up to the linguistic concerns of the humanist movement, it would be difficult to understand the Reformation in Germany.

Luther's great interest in the three sacred languages must be taken as a sign of his pursuit of the humanist ideal of the tri-lingual man, vir trilinguis, versed in the "sacred philology" 11 of the Latin, Greek, and Hebrew languages. Like other humanists, Luther began to apply his language skills to biblical texts, "infringing on an area that was traditionally regarded as the monopoly of theologians." $12 \mathrm{He}$, like other biblical humanists, studied Greek and Hebrew in order to find out the original meaning of the biblical words, as they went "to the sources" (ad fontes) and sought the "Hebrew truth" and the "Greek truth" of the Word of God. ${ }^{13}$ Luther made great efforts to master both Greek and Hebrew (whether he did so is not the issue here), and at every occasion he applied his linguistic insights in his exegetical and pastoral work. ${ }^{14}$ In his role as a monastic, biblical humanist and later Reformer, he pursued the "literal truth" of the Scriptures, "commonly regarded as the most sensational doctrine of the Reformation." 15

Luther's famous Ninety-Five Theses of 1517 mirror some of his linguistic insights. Yet, in a recent study of the "Textuality of the Ninety-Five 
Theses," 16 their polyglot aspect was not taken into consideration. Luther's very first thesis is based upon his Greek language study of Matthew 4:17: "When our Lord and Master Jesus Christ said, 'Repent,' he willed the entire life of believers to be one of repentance." Following Erasmus, Luther interpreted the Vulgate version of Matthew 4:17 (poenitentiam agite) on the basis of the Greek $\mu \in \tau \alpha \nu o \in \hat{i} \tau \epsilon$ and concluded in his thesis 2 that this word cannot be understood as referring to the sacrament of reconciliation, that is, private confession as administered by the clergy. ${ }^{17}$

There is thus good reason to call Friar Luther a young humanist and specifically a representative of "monastic humanism" (Klosterhumanis$m u s),{ }^{18}$ so that the question of Brian Cummings as to whether Luther was a scholastic or a humanist ${ }^{19}$ can be answered definitively in favor of the latter. There is no question that Luther's contemporaries situated him in the camp of the humanists, as the rectorate page illustrates.

The Nuremberg humanist, Willibald Pirckheimer (1470-1530), expressed his views on what humanists should be in his Epistola apologetica for Johannes Reuchlin (1455-1522), addressed to Lorenz Beheim on 30 August 1517.20 According to him, a true humanist theologian has studied first of all the three ancient languages (Latin, Greek, and Hebrew), Siquidem praeter grammaticam litteras latinas, graecas et hebreas callere necesse est. He considered such universally educated people, with moral integrity, to be the "true theologians," who do not need training in scholastic speculations but primarily in the study of the Bible and the Church Fathers. ${ }^{21}$ Pirckheimer's list of those that meet his criteria includes men that are still known today (Johannes Geiler von Kaisersberg [1445-1510] or Erasmus of Rotterdam [1466/69-1536]), but also others that are forgotten (Johannes Cuno [c.1462/63-1513] or Benedictus Chelidonius [14601521]). ${ }^{22}$ The Augustinian Canon Kilian Leyb (or Leib, 1471-1553) is mentioned explicitly as being learned in the three languages. ${ }^{23}$ Also mentioned is Luther's superior, the vicar general of the Saxon reformed congregation of the Augustinian order, Johann von Staupitz (1468?-1524), ${ }^{24}$ and several members of this order who are called sacrae theologiae doctores, including Wenceslaus Linck (1483-1547), ${ }^{25}$ Wolfgang Volprecht (d. 1528), ${ }^{26}$ Johannes Lang (1487-1548), and Martinus Lueder (i.e., Martin Luther, 1483-1546). Pirckheimer's list demonstrates that monastic humanists were well integrated into the entire movement we call humanism. The leader of the Augustinians, Staupitz, was apparently successful with his request of 14 November 1516 that Friar Johannes Lang should contact Pirckheimer in Greek and in Latin, "so that he finally will acquit our Augustinian congregation of barbarism." 27 
Pirckheimer's list was not meant to be comprehensive. There were other monastic humanists who aimed at mastering the ancient languages. For instance, among the Augustinians one finds the Jewish convert Felix de Prato (d. 1539 in Rome) ${ }^{28}$ and Caspar Amman (1450-1524). ${ }^{29}$ Friar Amman was convinced that "the Hebrews drink from the source, the Greeks from the small creeks, and the Latins from the swamp" - an inscription found on a wall of his friary at Lauingen, Germany, where this then-renowned Hebraist resided. ${ }^{30}$

Greek and Hebrew were used on the title-page of the encyclopedia on Germany, Germaniae exegeseos volumina duodecim, by the young humanist Franciscus Irenicus (1495-1559), a friend of Melanchthon, which was published at Hagenau and Nuremberg in 1518 with the printing privilege of Pope Leo X. The title-page shows two little angels, each carrying a scroll with the name "Jesus," the one on the left in Greek letters, the one on the right in Hebrew letters. According to this book, the Augustinian trio that showed openness to humanist concerns was the following, with their names listed in this order: Linck, M. Luder [sic], Staupitz. ${ }^{31}$ On the same page (with his name spelled as Lutherus), Irenicus featured Friar Luther for his outstanding theological erudition. This distinction may mark the beginning of Luther's fame and glory following the Heidelberg Disputation. ${ }^{32}$

A further example of monastic humanism is provided by Abbot Johannes Trithemius (1462-1516), who lived at a Benedictine monastery where a trilingual inscription of a psalm may still be found today on an arch above a door. ${ }^{33}$ It is noteworthy that the young Friar Luther read Trithemius and made a few remarks in the margins. ${ }^{34}$ Another such figure was Vitus Bild Acropolitanus, an early sympathizer of Luther at the Benedictine monastery in Augsburg. ${ }^{35}$ Among the Cistercians, Conradus Leontorius (c.1460-1511) was known as a biblical humanist and was praised by Trithemius as an "expert in the three principal languages." 36

In featuring here the multilingual efforts of the German humanists, it is taken for granted that they favored classical Latin (in contrast to medieval, ecclesiastical Latin) in their writing and communication with each other, and that they often Latinized their names. The humanist priest Konrad Muth, or Conradus Mutianus Rufus (1470-1526), a canon at Gotha, often spoke of the humanists as the "order of the Latinists" (ordo latinus). ${ }^{37}$ Cultivating Latin was a given.

The study of Greek was also definitely on the rise. At Erfurt the printer Wolfgang Schenck established the first Greek press in 1499, that is, he invested in the cutting of Greek letters for his press. Two years earlier, in 1497, Anton Koberger had begun using Greek letters in his print shop at Nuremberg. ${ }^{38}$ Konrad Fyner (Feyner) had printed Hebrew letters with a guide to pronunciation as early as 1477 in the book of Peter Niger (Schwarz), 


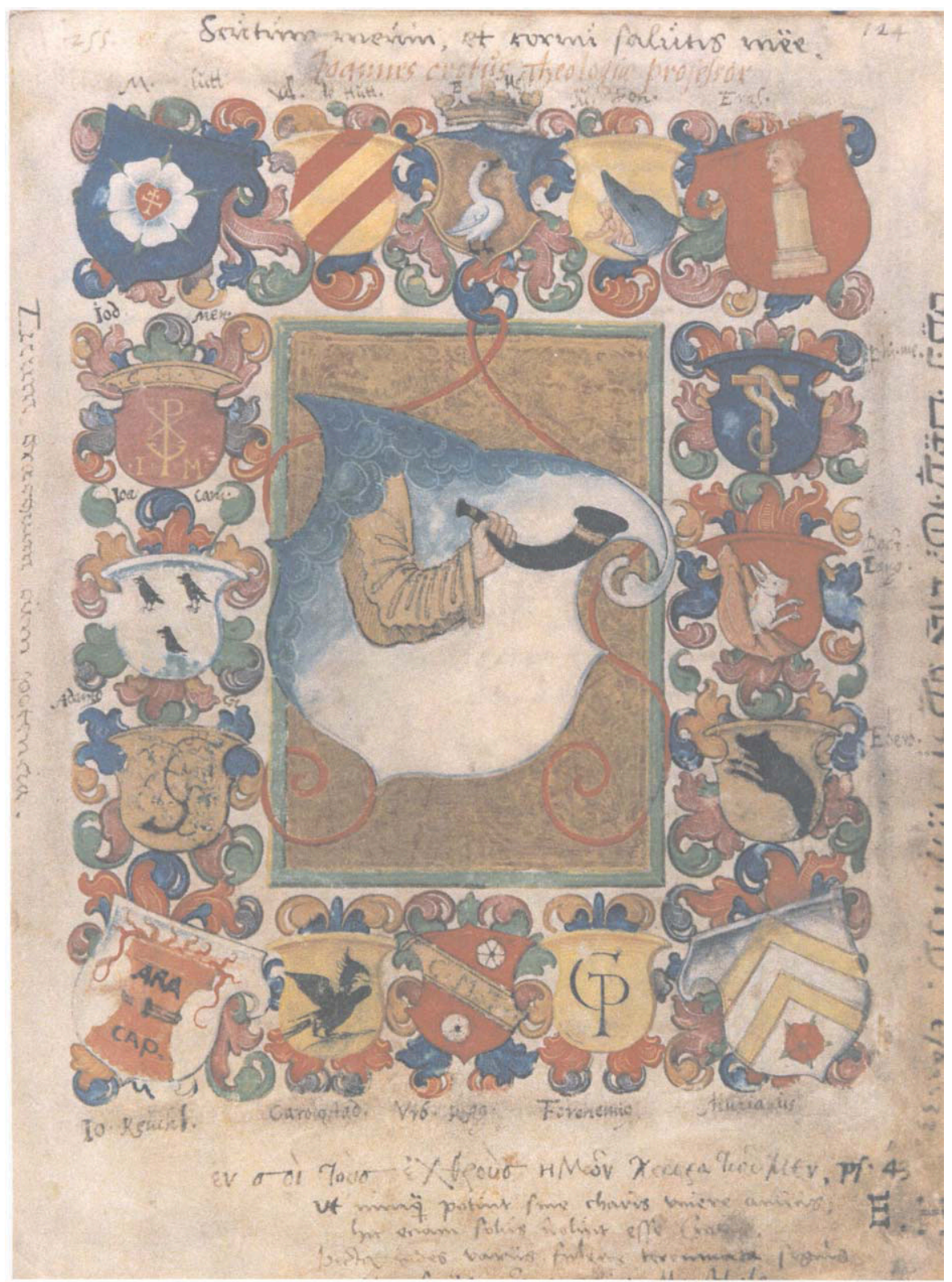

Rector's Page of c. 1521. Stadtarchiv Erfurt, Germany, Erfurter Universitätsmatrikel, vol. 2, p. 124. Reproduced with permission of Stadtarchiv-direktor Dr. Benl. 
Stern des Meschiah (Star of the Messiah), in his shop at Esslingen in southwestern Germany. ${ }^{39}$ Books written in Hebrew were, however, primarily imported from Italy. ${ }^{40}$

\section{Polyglotism on the University Rector's Page of 1521}

Polyglot humanism is the context in which one must place the rectorate page of 1520-21 of the humanist priest Crotus Rubeanus, since it includes quotations in Hebrew, Greek, and Latin. This document represents the intellectual milieu in which Luther lived. On it, a prominent place was given to him, and he was thus recognized as a conscientious humanist friar from the newly founded University of Wittenberg, but with ties to the friary of Erfurt, and thus as a "monastic humanist" who was welcomed on the page of the Erfurt rector.

In commemoration of his term of office as rector, Crotus had his family coat of arms depicted in the center of this colorful, uncommonly large page: ${ }^{41}$ a hunter's horn held by a hand, an allusion to his pre-humanist name Jäger, which is German for hunter. However, he also included sixteen smaller coats of arms, seals, or shields of his humanist colleagues and friends, whose emblems form the framework of his coat of arms at the center.

Crotus was the principal author (together with his friend, Ulrich von Hutten [1488-1523]) of the famous Letters of Obscure Men (Epistolae obscurorum virorum) ${ }^{42} \mathrm{He}$ received his master's degree at Erfurt in 1507, his doctoral degree in theology from Bologna in 1520, from where he wrote a letter to Luther. ${ }^{43}$ Upon his return from Italy, where he had stayed from 1517 to 1520 , he paid a visit to his alma mater Erfurt, when he was surprised to be elected to the office of rector of the university. Since he held this position from 18 October 1520 to 2 May 1521, one may safely assume that his rectorate page was created during that time, or shortly afterwards.

That one of the emblems displayed belonged to a Cistercian monk was not always clear. ${ }^{44}$ In the nineteenth century, the discrepancy was noticed between the Cistercian's emblem and the name that was ascribed to it in a handwritten abbreviation of a later date, that is, Urbanus Rhegius. The latter was not associated with the Erfurt humanists around Crotus. ${ }^{45}$ Today the ascription to the Cistercian monk Henricus Urbanus (c.1470-1538) is no longer questioned. ${ }^{46}$ His shield/seal includes a religious motto with the abbreviation, C. M. T., which stands for Christus mundum transigit (Christ overcomes the world). ${ }^{47}$ This Cistercian was the "best and greatest friend" 48 of the leading humanist at Gotha/Erfurt, Mutianus. The latter is represented on Crotus's page as a key figure in one of the four corners. Mutianus had designed the seal/shield for Urbanus, with its symbol of one half of a carriage 
(rotae dimidium), ${ }^{49}$ that is, two wheels of a four-wheel wagon, as shown on the page. Mutianus gave this witty reason for his design: since Urbanus as the steward of his monastery did not have his own seal yet, he (Mutianus) wanted to assist him in finding one, at least one half of a wagon. The two wheels are a reminder that the city he lives in belongs to two bishops, of Mainz and of Osnabrück, who both claimed the entire four-wheel wagon. Furthermore, Mutianus wrote that he read in the books of Saint Bernard that this most holy father (i.e., of the Cistercians, to whom Urbanus belonged) once had lost his own seal and needed a new one. And, after all, the ancient poet Hesiod once said that half is better than the whole, that is, he preferred the moderate to the immoderate. 50

Membership in a monastic order played, however, no decisive role in the inclusion or even in the positioning of the coats of arms on this sheet. Neither did the age of the humanists, except that the older ones among them were already well known by 1520-21 and perhaps for that reason occupy the four corners of the frame of the page: Reuchlin, the oldest (born in 1455), Erasmus (born in 1466?), Mutianus (born in 1470), and Luther (born in 1483). Most of the others were born in the 1490s; the youngest appears to be Camerarius, who was born in 1500.51 These men were in their twenties at the time, but evidently already worthy of the privilege of sharing the spotlight on the rector's page.

More important than age and affiliation with a religious order was apparently another factor: the arrangement of the shields was influenced primarily by considerations of the humanists' interest and expertise in the sacred languages, Hebrew, Greek, and Latin, an essential mark of Renaissance humanism. The tri-lingual man (vir trilinguis) was the humanists' ideal, promoted by Erasmus of Rotterdam. There was the Trilingual College in Louvain ${ }^{52}$ where Nicolas Marschalk (or Marescalcus Thurius, c.14701525 ) received his bachelor's degree (however, before the trilingual college was established). He transferred to Erfurt in order to study for his master's degree in 1496. Here he met Mutianus, an expert in Greek. Marschalk soon promoted there the ideal of the trilingual scholar, that is, at the beginning of the sixteenth century, in 1502, before he joined the faculty of the liberal arts at the newly founded University of Wittenberg. ${ }^{53}$ Among Marschalk's students at Erfurt was Crotus Rubeanus. Other students of Marschalk were Georg Spalatin (1484-1545), Johannes Lang (1487-1548), Johannes Draco (or Drach, Draconites, 1494-1566) from Karlstadt, and Hermann Trebelius (c.1475-1514). The latter demanded that theologians should learn Greek because the New Testament was written in Greek. ${ }^{54}$ Among Marschalk's students, only Lang and Draco were included on Crotus's page. ${ }^{55}$ 
A sm entioned, C rotus's page is rem arkable; it show s fourhand-w ritten polyglot inscriptions, which are variations of one $m$ otto in the three sacred languages, $w$ ith the com $m$ on denom inator to be found in the tw o key words: "hom" (of salvation) and "arm" (of G od). On the top of the page, one reads the Latin version of 2 Sam uel 22:3, taken from D avid's song of thanksgiving for having been saved from his enem ies: "scutum meum et comu salutis mëe [meae]" (" Eyou, Lord are] my shield and the hom of m y salvation") . ${ }^{56} \mathrm{O}$ n the leftm argin one reads parts of a Latin version of Psalm 89:11: "Tuum brachium cum potencia" ("yourarm [has scattered yourenem ies] w ith pow er") , given here in a hum anist Latin version, not in the Vulgate. U nder the bottom row of shields

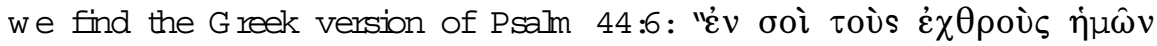
$\kappa \in \imath \rho \alpha \tau \imath$ loû $\mu \epsilon v^{\prime}$ ("Through you we struck dow n ourenem ies") .

The H ebrew inscription on the rightm argin is taken from Isaiah 33.2 w ith the key w ord זר ("arm "). H ow ever, the sequence of the H ebrew w ords is inconrect, and one w ord is om itted..$^{58}$ The H ebrew w ord for "in the m oming," צִ צִרָה ("trouble," "necessity" ) is not only $\mathrm{m}$ isplaced but also spelled inconrectly. A ny beginning student of $\mathrm{H}$ ebrew has a hard tim e differentiating the H ebrew lettery (sâdê) from $\nu$ (ajü), and the w riter of these w ords confused them, too. This lack of linguistic skill indicates thathe $w$ as notyet an expert in this language. The $\mathrm{H}$ ebrew vow els are notalw ays conrect, and the handw riting of the H ebrew w ord for "our salvation" is so im precise, or inaccurate, that it is hard to recognize. The tw o H ebrew letters for the sound " $t$ " are $m$ ixed up in the w ord $n y$ ("in tim e of"), since the w riterhas $\mathrm{m}$ istakenly w ritten $\mathrm{V}$ (têt) where he should have used $\Pi$ (tâw ). The

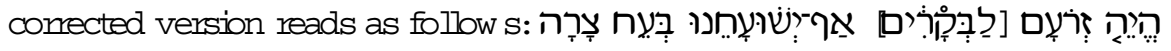
("Be our arm every m oming, our salvation in tim e of trouble").

$\mathrm{W}$ hen one reads these trilingual biblical quotations in the sequence starting on the left $w$ ith Psalm 89:11, counter-clock-w ise, one gets the follow ing series:

Y our arm has scattered your enem ies] w ith pow er (Ps. 89:11); Through you we struck down our enem ies (Ps. 44:6); Be our arm every m oming, our salvation in tim e of trouble (Isa. 33.2); [Y ou, Lord are] my shield and the hom of my salvation (2 Sam .22:3).

These four quotations are m eant as encouragem ent to rely on G od's help alone in tim es of trouble. They express the situation in which the Erfurt hum anists found them selves, being a m inonity in the scholarly w orld of Enfurt, which at that tim e was dom inated by scholasticism . ${ }^{9}$ In addition, the $\mathrm{D}$ iet of $W$ orm s was in session from January to M ay 1521, which resulted in the ban against Luther, one of their friends. On his way to the $\mathrm{D}$ iet of $\mathrm{W}$ orm $\mathrm{S}$, 
he had been greeted by a welcoming committee, led by Rector Crotus, at his stop-over at Erfurt on 6 April 1521.60 This was the best reception Luther had ever received in any city. One must not forget that he was still a friar, and, of course, he stayed overnight at his old friary. ${ }^{61}$ Rector Crotus recorded these observations about his former roommate:

At this time CHARLES V held his first Diet at Worms, at which the highest imperial affairs were hard discussed for four months, with the affair of MARTIN LUTHER, who dared as the first after so many centuries to chastise Roman pride with the sword of Holy Scripture. ${ }^{62}$

This is the time when the humanist "reform party" developed into "a reformation movement," 63 which appears to have been a minority still. A Latin four-liner signed "E. H." (Eobanus Hessus) expresses some of their feelings of isolation and need of friends. After all, Hessus was the only humanist who had obtained a professorship at Erfurt (since 1518). He put the sentiments that came to the fore with the Scripture quotations in the three sacred languages that were entered on Crotus's page into these words:

As Crotus could not live without his dear friends, so here [on this page] he did not want to be by himself either. You see [their] shields depicted as they shine with various signs; he was the rector to these associates of our school. E. H. ${ }^{64}$

\section{Who Is Represented?}

That Luther is found in the company of Erfurt humanists may initially have been due to the fact that he and Crotus were roommates in the Georgenburse at Erfurt. ${ }^{65}$ Crotus must have felt that Luther was one of their own, and with good reason, as he developed into an admirable polyglot humanist. A closer look at the emblem in the upper left corner makes one question - momentarily - the ascription to Luther, since the "Luther Seal," known as the "Luther Rose," as it is shown here contains a peculiarity which is not found in Luther's own later description of his shield/seal. Crotus's page shows a papal cross (!) with three horizontal cross beams inside the Luther Rose, while Luther described its center as showing a simple black cross. The golden ring surrounding the rose is also missing from the depiction of $1520 / 21 .{ }^{66}$ No one seems to point out these discrepancies or challenge the ascription of this coat of arms to Martin Luther. Thus, as long as there is no alternative in sight, one may indeed assume that it is Luther's. Luther therefore occupies a key position in the lay-out of the rector's page, to which we may now turn our attention. 
1. The top row of emblems: Luther, Hutten, Hessus, Jonas, and Erasmus The men who are represented here may have in common an anti-papal and a German-national orientation. German "national humanism" or "patriotic humanism" 67 may have played a role, though a secondary one, in the arrangement of the shields in the top row. German humanists and patriots in general were often at odds with the Roman curia. ${ }^{68}$ The concept of a "nation" around 1500 is, however, complex and in need of further clarification. ${ }^{69}$ Occasionally, German humanists displayed their patriotism by contrasting Germany with a loquacious Greece, a presumptuous Italy, and a quarrelsome France. ${ }^{70}$ Yet these nationalist humanists nevertheless conversed in Latin, and most of them aimed at the trilingual ideal.

A special place was reserved in the center of the top row of the rector's page, where we see the shield of Eobanus Hessus (1488-1540) with a royal crown as the sign of his status as a celebrated poet. ${ }^{71}$ Hessus' position of honor was due to the fact that Reuchlin had given him the honorific title "king," alluding to him as the "Hessaen" (from Hessen), which sounds like the Greek word for "king." 72 Hessus was the author of a praise of Germany in 1506: De laudibus et praeconiis incliti atque totius Germaniae. ${ }^{73}$ His most popular work, years later, was an edition of Psalm 118 in descriptive Latin distiches. ${ }^{74}$ (Luther had inspired him to undertake this, sending Hessus his scholion on the "beautiful confitemini" [Psalm 118] on 13 December 1529). ${ }^{75}$

Hessus celebrated Luther's visit at Erfurt on his way to Worms in nationalistic poems, calling Luther the defender of the Word of God against the deceit of Rome. ${ }^{76}$ With some exaggeration he celebrated him in these words: "Luther was the first in our times who not only saw the weed in Christ's field, but dared to weed out all that is noxious with a strong hoe and hand." 77 And he addressed to Luther the assurance that "Germany will stand up in arms for you."78 Hessus dedicated the second elegy to Crotus, whose coat of arms is at the center below Hessus's own; the fifth elegy he dedicated to the priest Justus Jonas (1493-1555), "the theologian who went with Luther to see the emperor" and who flanks Hessus at the right between him and Erasmus. Hessus's sixth elegy is dedicated to Ulrich Hutten as "the knight and poet" who flanks Hessus on the other side next to Luther. ${ }^{79}$ Jonas in turn found praise for Hessus as a "German prophet." 80 Around 1520 Hutten was still hopeful that Erasmus would side with him and Luther against Rome. ${ }^{81}$

The nationalist tendencies among German humanists were not felt to be in contradiction to the humanist ideal of learning foreign, sacred languages, because the study of Greek and Hebrew was understood as the necessary precondition for the correct understanding of the Scriptures as the Word of God, which needed to be proclaimed to one's own people in the vernacular. 
The patriotic Luther, eagerly learning Greek and Hebrew, apparently had no problem even about using the Graecized version of his own family name, i.e., Eleutherius, a self-designation that is demonstrable from 11 November 1517.82

The humanist Luther rightfully received a prominent placement on the rector's page. After all, the University of Erfurt was his alma mater, ${ }^{83}$ and he became known as the editor of the Theologia Germanica in 1516 (reedited in 1518$)$. He proudly wrote in his preface:

I thank God that I can hear and find my God in the German tongue, the way I do here, in a manner in which I and the German theologians with me so far did not find Him even in Latin, Greek, or Hebrew. God grant that this little book may become increasingly known. It will then be confirmed that the German theologians are no doubt the best theologians. Doctor Martinus Luther, Augustinian at Wittenberg. ${ }^{84}$

His nationalism came through also in his lectures on Romans in 1516, as he declared that the "Germans prefer the German poets," as the French prefer theirs. ${ }^{85}$ It is not surprising, then, that Luther was considered a leader of the German theologians, according to Franciscus Irenicus (1495-1559) in his Germaniae exegeseos volumina duodecim of 1518. Luther's pamphlet To the Christian Nobility of the German Nation Concerning the Reform of the Christian Estate appeared at that time, i.e., in August 1520. During the same summer, students at Erfurt seized copies of the papal bull against Luther and threw them into the river. ${ }^{86}$ The major event, however, occurred at Wittenberg in December 1520, during Crotus's term of office at Erfurt, as Luther burned the papal bull in public.

Anti-Roman feelings were running high at this time and were passionately expressed by Hutten. As a German patriot, Hutten found his spot on Crotus's page next to Hessus. Hutten himself had been crowned poet laureate by Emperor Maximilian in 1517. Hutten had profited from having Crotus as his mentor when he was a student at Erfurt in 1503.87 Crotus had helped Hutten to escape from the monastery in Fulda where his father had placed him at a very young age. Hutten complained that theologians had departed from "the good old German theology" (vetus et germana), perhaps playing on the double meaning of "germane" (real, true). Hutten complained that the Sacred Scriptures were not understood correctly without the knowledge of Hebrew, Greek, and Latin. ${ }^{88} \mathrm{He}$ also was the author of the "complaints and warning against the extreme, unchristian power of the pope in Rome" of 1520 (Clag und Vormanung gegen übermäßigen unchristlichen Gewalt des Bapsts zu Rom). In another anti-Roman booklet of the same year, which in the vernacular is called Vadiscus oder die Römische Dreifaltigkeit, he went so far as to ask why the Germans did not take up arms yet against Rome. ${ }^{89}$ 
After the summer of 1520, when Hutten was excommunicated, he felt compelled to take refuge at the Ebernburg castle of his friend, Franz von Sickingen (1481-1523). From there he continued launching poisonous pamphlets against the papacy. ${ }^{90}$ Hutten had been prepared for these attacks by, for example, his study of the work of the Italian humanist Lorenzo Valla (1406-57) on the "Donation of Constantine." At the end of the year 1518, Hutten reedited Valla's book, which had been published in $1506 .{ }^{91}$ Hutten expected the popes to be successors of Saint Peter, not of the Emperor Constantine. Popes should teach by preaching and by leading exemplary lives. Erasmus had written to Jonas with similar complaints about the worldly behavior of the prelates and mentioned Saint Bernard of Clairvaux (1090-1153) as his authority. ${ }^{92}$ In this demand, the humanists relied on Bernard's On Consideration, a work originally written as advice to a pope (Eugene III). ${ }^{93}$

In the row of German patriots on Crotus's page, the emblem of Canon Justus Jonas, professor at Erfurt, church lawyer, and theologian, was placed to the right of Hessus and to the left of Erasmus, whom he admired. He was elected in absentia to the rectorate of the university in 1519, before he had returned from his visit with Erasmus in The Netherlands. During Jonas's term of office, the study of Latin, Greek, and Hebrew was promoted, and the humanist ideal of the trilingual college became a reality at Erfurt in the winter semester of 1519, as Jonas, with the help of his friends Hessus, Draco, Lang, and Petreius, recruited faculty for the study of the three sacred languages. ${ }^{94}$

Jonas accompanied Luther to the Diet of Worms in the spring of 1521. Afterwards, Jonas moved to Wittenberg to succeed the deceased Henning Goede (c.1450-1521), 95 the dean of the Schlosskirche (Castle Church), on whose door Luther later supposedly nailed his ninety-five Theses. At Wittenberg Jonas became a doctor of theology, also in 1521.96 Spalatin had written a letter of recommendation for him, in which he called Jonas a pious and learned priest, and "wonderfully eloquent in both Latin and German." 97 Jonas appears to have had a fine sense of the German language, as the Wittenberg Reformers usually turned to him for translations of their Latin works into German and conversely from German into Latin. ${ }^{98}$ Occasionally even Melanchthon gave his German writings to Jonas for polishing. Jonas was also the translator of the revised version of Melanchthon's Loci of 1535. Luther wanted Jonas to put his commentary on the Prophet Jonah, written in "barbaric and unrefined language," into an "elegant and brilliant style." 99 At the time when Crotus's page came into existence, Luther was being sheltered at Wartburg Castle, where in May 1521 he wrote his book against 
Jacobus Latomus (c.1475-1544) and dedicated it to Jonas. ${ }^{100}$ At Wartburg he began the translation of the New Testament into German.

The top row of emblems ends with that of Erasmus in the right corner of the page. Both Erasmus and Luther were already known as critics of the popes. Erasmus had written a satire against Pope Julius II, his Julius Exclusus of $1518 .{ }^{101}$ In a letter to Friar Lang, dated in the fall of 1518, Erasmus called the papacy a pestilence in Christianity. 102 With these observations in mind, we may call this row of shields the row of German anti-Romanists. Even Erasmus occasionally spoke of "my Germany." $103 \mathrm{He}$ is therefore placed appropriately in the line of Germans along with Luther and the others. However, Erasmus is known more for his expertise in Greek. $\mathrm{He}$, too, aimed at mastering all three sacred languages, although he soon gave up on Hebrew. ${ }^{104}$ Erasmus' sympathy for Old Testament studies was "lukewarm" and for Jewish studies "non-existent."105

\section{The line of emblems on the right side, from top to bottom: Erasmus, Melanchthon, Lang, Petreius, and Mutianus}

The entire column is headed in the upper-right corner by Erasmus. In 1516 he had published the New Testament in Greek and included his own Latin translation. Philip Melanchthon (1497-1560) was "an adopted Erfurter."106 He became professor of Greek at Wittenberg on the recommendation of his uncle Reuchlin. Melanchthon resided at Wittenberg from 1518. From there he visited Erfurt in December 1520, that is, during Crotus's term of office as rector. He stayed at the homes of the humanists Georg Forchemius and Camerarius, ${ }^{107}$ whose shields are included on Crotus's page (Melanchthon's Forchemius', and Camerarius'). Melanchthon, as the rising star of Greek scholarship, was apparently "adopted" by Crotus for the purpose of displaying the shields of the multilingual scholars on his page. There is no other apparent reason for Melanchthon's inclusion other than his polyglotism and friendship with Luther.

The family coat of arms of Friar Johannes Lang (1487-1555) is situated in the middle of the right margin; it shows, against a red background, a rabbit coming out of a cleft. Lang taught Greek and lectured on Demosthenes in Erfurt, for which his students nicknamed him the Erfurt Demosthenes. ${ }^{108}$ In 1515 he worked on the Church Father Jerome. ${ }^{109}$ When he was teaching at Wittenberg he gave lectures on the Greek New Testament. We know of lectures on Saint Paul's Letter to the Romans 110 that are ascribed (falsely?) to Lang and of his lectures on the Letter to Titus, ${ }^{111}$ which are definitely his own. He explained the Vulgate text from the Greek, periodically noting that the Greek text has it in a certain way (Graecus habet; Graece dicitur), as, for example, on Titus 1:3-5. He also included Greek words on a regular basis. 
Lang may actually have tutored his confrere Luther in Greek, since at the same time he was delivering his lectures on the Letter to the Romans. ${ }^{112}$ Lang also knew Hebrew and helped Luther with his study of that language. He provided Luther with the Hebrew textbook by Wolfgang Faber, Institutionuncula in Hebraeam Linguam (Basel, 1516). ${ }^{113}$ Since the early summer of 1521 Lang continued his biblical studies. He worked out his own, rather literal translation of the Gospel of Matthew from Greek into German, based upon Erasmus's Greek edition of the New Testament. 114 This was the first German translation directly from the Greek of the New Testament edition of Erasmus. ${ }^{115}$ Whether Luther profited from it in his own work on the translation of the New Testament is still to be investigated.

As for the linguistic skills of Peter Eberbach, called Petreius (c.14801531), a "doctor of the literary discipline" since 1508,116 we know that he wrote Latin epigrams (Epigrammata in Eduardum Leeum [Erfurt, 1520]) in defense of Erasmus when the latter was under attack by Edward Lee. 117 Petreius (and also Adam Crato) defended Erasmus passionately. This may explain his placement in this Greek column in the company of Erasmus, while the emblem of Conradus Mutianus Rufus (1470-1526), the acknowledged expert on Greek, forms the basis of this column (on the right). Petreius was not only a Hellenist, but also a learned Hebraist (hebraice eruditus), according to Spalatin's statement in a letter to Lang. 118

\section{The bottom row of emblems from left to right: Reuchlin, Draco, Urbanus, Forchemius, and Mutianus}

In this line-up Mutianus is positioned in the right corner, while Reuchlin, the Hebraist and playwright, takes his place at the other end in the lower-left corner. The young Reuchlin wrote two witty and successful Latin comedies, Sergius and Henno. Reuchlin, the Latinist and Hebraist, and Mutianus, the Latinist and Graecist, each at the end of this row, thus symbolize the foundation stones of German multilingual humanism. Between these two nestors of the humanist movement in Germany are situated Johannes Draco (1494-1555), ${ }^{119}$ Henricus Urbanus (c.1470-1538), and Georg Petz Forchemius (i.e., from Forchheim, c.1500-22). The place of honor, at the center of the row, is assigned to Urbanus, the procurator of the Cistercian monastery of Georgenthal and its branch house at Erfurt. As early as 1505, Mutianus assumed in a letter that Urbanus understood the Greek word for "fish eaters," 120 although we are uncertain about the degree of his expertise in Greek. Urbanus' outstanding knowledge of classical Latin is beyond doubt. Mutianus addressed him occasionally as an "ingenious and Latin man."121 In another letter of Mutianus, written before 1505, the Cistercian monk is 
honored with a poem that calls him a man eager to make use of Latin. ${ }^{122}$ Nothing, however, is known about Urbanus' knowledge of Hebrew.

Urbanus is flanked on the left by Johannes Draco and on the right by Georg Petz Forchemius. The latter earned a bachelor's degree at Wittenberg in 1521 and then returned to Erfurt. Here the young scholar (likely influenced by ideas from Wittenberg) and some other students disrupted a disputation presided over by Arnoldi von Usingen (c.1464-1532), who, because of their rude behavior, left the disputation in protest. ${ }^{123}$ Forchemius was one of the electors who voted Crotus into office, and this may be the main reason that, despite being such a young man, he was included in the rector's page. ${ }^{124}$ In the early 1520s, Forchemius and the by-then ex-Augustinian Lang were the best-known preachers at Erfurt who sided with the reformers. ${ }^{125}$ Forchemius, still very young, died suddenly in the pulpit while preaching on 10 July $1522 .{ }^{126}$

Draco, an Erasmian who studied at Erfurt from 1509 to 1514, was a canon at Saint Severus' church in Erfurt (along with Justus Jonas). In 1520 he visited Erasmus. Draco was known for arranging theatrical presentations in Latin, particularly of comedies, in his house. ${ }^{127}$ On 9 April 1521 the canon was expelled from his position for supporting Luther. ${ }^{128}$ His scholarly goal was to publish a polyglot Bible at Wittenberg, for which he spent most of his income. Much later, in 1563-65, his Biblia pentapla (in five languages) was finally published. ${ }^{129}$ Considering Draco's role as host of Latin theatrical productions, Reuchlin's authorship of Latin comedies, and the others' interest in refined Latin, we may call this the row of the Latinists.

\section{The line of emblems on the left from bottom to top: Reuchlin, Crato, Camerarius, Menius, and Luther}

On the left side of the rectorate page, as expected, we find the Hebraists, starting with Johannes Reuchlin, author of the famous Hebrew textbook, De rudimentis Hebraicis of 1506, which formed the basis of Hebrew studies in Germany. In 1512 he published a book on the Seven Penitential Psalms with a literal Latin translation based upon the Hebrew original: In Septem psalmi poenitentiales hebraici cum grammaticali translatione latina. It was the first full Hebrew Bible text printed in Germany. ${ }^{130}$ Luther used it for his own publication on these same psalms in 1517, Die Sieben pusspsalm mit deutscher auszlegung nach dem schrifftlichen synne, as Luther himself indicated in his preface. ${ }^{131}$ Reuchlin was at the center of the storm of attacks by those who favored the burning of all Hebrew books. In his defense, Crotus, Mutianus, and others circulated the Letters of obscure men.

The column is headed by Martin Luther in the upper left corner. Already as a young friar, when he had to lecture on Lombard's Sentences (probably 
in 1509), he was interested in Hebrew and Greek. He entered Greek words in the margin. ${ }^{132}$ At that time he already possessed Reuchlin's De rudimentis hebraicis. In search of the original meaning of the Scriptures, Luther noted in one of his marginalia on Lombard that at that point the "Hebrew truth" (hebraica veritas) ${ }^{133}$ was at issue. With the help of Reuchlin's textbook, Luther in four instances discussed Augustine's allusions to certain Hebrew names. ${ }^{134}$ Luther also used Hebrew words in his notes, as, for example, on the Vulgate notion firmamentum, in order to contrast the Vulgate version with the original Hebrew. ${ }^{135}$ Already in 1516 Luther was anxious to read the brand-new edition of Jerome's works; his marginalia in his desk copy contain Greek and Hebrew words. ${ }^{136}$

Encouraged by Melanchthon, Luther sent a letter to Melanchthon's great-uncle, Reuchlin, on 14 December 1518, to congratulate him on the felicitous outcome of Reuchlin's trial in Rome. ${ }^{137}$ Thus, Luther placed himself squarely in the humanists' camp, as is further demonstrated by the fact that the letter was published in May 1519, together with the Illustrium virorum epistolae, hebraicae, graecae et latinae, ad Ioannem Reuchlin Phorcensem missae, printed by Thomas Anshelm at Hagenau. ${ }^{138}$ In his letter, Luther used the Hebrew word Behemoth, which means a four-legged animal like a hippopotamus, perhaps alluding to Job 40:15. He employed this image of an animal, strange to Europeans, as a metaphor for the pope: "The teeth of this Behemoth attack me, as if by doing so they would be able to repair the disgrace which they have [now] taken away from you."139

By 1520-21, Luther was apparently well known for his knowledge of Hebrew, which he applied in his interpretations of the Psalms. ${ }^{140}$ After several years as professor of the Bible, in the spring of 1517, he published an often-overlooked booklet in German, his first publication, on the Seven Penitential Psalms. The German title clearly expresses his intention of interpreting these psalms literally (schrifftlich) for everyone: Luther spread to a wider readership what he had learned from Reuchlin's Hebrew scholarship. In Luther's exposition of the seven psalms one finds references to the Hebrew original, such as the following: "therefore, the Hebrew has it [this way]" (darumb hat das hebreisch). ${ }^{141}$ Luther's book was reprinted nine times between 1517 and 1525 . The seal of Luther, which is positioned in the upper left corner of the rectorate page, is thus the connection not only to the seals of the German, anti-papal humanists in the top row, but also, and perhaps more importantly, to the emblems of the Hebraists in the left margin.

Little is known about the knowledge of Hebrew of the three other men in the column, those who are stationed between Luther on top and Reuchlin at the bottom. Perhaps Crotus filled up this column with the shields of young men with an interest in the old languages, not specifically Hebrew. We know 
that the young Joachim Camerarius (1500-74), ${ }^{142}$ who is placed in the middle between Menius and Crato, benefited from the humanist reforms at Erfurt and was one of the first graduates who blossomed (pullulantis) with a sound knowledge of Latin, Greek, and Hebrew. ${ }^{143}$ He later became one of the most eminent philologists in sixteenth-century Germany, professor of the ancient languages at the Universities of Tübingen and Leipzig. ${ }^{144}$ Yet, Camerarius is more known for his expertise in Greek than in Hebrew.

Camerarius taught Greek to his slightly older friend Justus Menius (or Jodocus Meni[n]g, 1499-1558), and Menius may have been placed next to him for this reason. Menius was also the nephew of Mutianus of Gotha. After studies under Melanchthon in Wittenberg up to 1523, Menius became a preacher at Erfurt alongside Lang. ${ }^{145}$ In the 1520s Menius, as a convinced Lutheran, would accuse Crotus of skillfully concealing his true (Lutheran) thinking by conforming to the traditions of the Church, such as singing the Salve Regina or taking part in processions. ${ }^{146}$ In 1527 Menius wrote against the theological positions of the Franciscan Conrad Kling at Erfurt; Menius' text was prefaced by Luther. ${ }^{147}$

Adam Crato (or Krafft/Crafft, 1498-1558) ${ }^{148}$ had been a pupil at the monastic school in Fulda. Beginning in 1512, he studied at Erfurt, graduating with a master's degree in 1519. He delivered humanist lectures there and was friends with Friar Lang and other local young humanists like Draco, Camerarius, and Jonas. ${ }^{149}$ Crato had introduced Camerarius to the circle of Eobanus Hessus. ${ }^{150}$ Crato, as an early follower of Luther, attended the Leipzig Disputation together with Friar Lang, and on that occasion Crato met Melanchthon. They shared a great interest in the study of Greek. ${ }^{151}$ After Crotus left Erfurt for Fulda, Crato followed him. ${ }^{152}$

\section{The shields in the four corners}

The emblems in the four corners are slightly bigger than the others. Luther thus appears as the fourth of the "great German humanists" besides Erasmus, Reuchlin, and Mutianus. ${ }^{153}$ In their corner-stone position, they appear to serve a double function, as they form the link to the connected rows. Luther is the connection between the column of Hebraists and the top row of nationalist anti-Romans. Erasmus is the connection between the anti-Roman row and the column of Greek scholars on the right margin. Mutianus is the connection between the column of Grecians and the bottom row of Latinists. Reuchlin is the connection between the row of Latinists and the column of Hebraists that is topped by Luther. One suspects that the rectorate page, with the pronounced positioning of the four men, may have served Crotus's interest in showing unity among them as the "four leaders" of a movement. ${ }^{154}$ 
There is perhaps also a diagonal correlation between Erasmus and Reuchlin: When Reuchlin died in 1522, Erasmus paid him the tribute of the eulogy, Apotheosis Capnionis (Reuchlin). In it he described the dream of a monk about Reuchlin entering heaven. Jerome, the patron saint of the humanists, was already waiting for the new saint. Jerome was wearing a white robe embroidered with colored letters of the Hebrew, Greek, and Latin alphabets, ${ }^{155}$ a celebration of humanist polyglotism.

There may also be a correlation along the other diagonal, between Mutianus and Luther. In the spring of 1515, Luther and other Augustinian leaders gathered at Gotha for their chapter meeting under the leadership of Johann von Staupitz. Mutianus resided at Gotha and was, of course, fully aware of the meeting of the Augustinians. He took notice of the "sharp" sermon which Luther delivered at that occasion. In his sermon on backbiting and the devil as the chief backbiter, Luther employed his rudimentary tri-lingual skills, as he spoke of the devil and his names in the three sacred languages: Satan in Hebrew, diabolos in Greek, and detractor in Latin. 156 Luther's display of polyglot humanist knowledge may have impressed Mutianus, the Hellenist and Latinist. It is therefore as a trilingual scholar that Luther may have received his rightful place in one of the four corners of the page, sharing the limelight in 1520/21 with Erasmus (with whom he had not yet entered into the debate over the free and enslaved will), with Reuchlin (who had not yet publicly shown his opposition to the reform movement from Wittenberg), and with Mutianus (who had not yet distanced himself from Luther) as the central figure of the humanists at Gotha. At this time, "many of the humanists were unanimous in their support for Reuchlin and Erasmus," and they "soon added Luther to their list."157

\section{Conclusion}

In a way, the iconographical lay-out of the entire rectorate page points to the typical humanist sodality, ${ }^{158}$ which, however, may have existed only in Crotus's imagination, as, for instance, Luther and Erasmus never met in person. Most of these men "net-worked" by exchanging letters in polished Latin. The humanists who are represented on Crotus's page never met as a sodality. Some of them were self-declared anti-ecclesial figures. Yet the rector's page includes two friars and a monk. That they were included is remarkable, insofar as Renaissance humanism is not seldom viewed as a secular phenomenon, from which churchmen, monks, and friars distanced themselves. These three clerics, the Cisterican Urbanus and the two Augustinians Lang and Luther, represent a specifically monastic humanism (Klosterhumanismus). 
The trilingual Scripture quotations surrounding the shields, with which God's power was invoked on behalf of the humanist minority, were meant to encourage or console them. These quotations are impressive testimony to polyglotism as an essential factor of humanist and theological identity and to the co-operation of monastic and non-monastic humanists at that time. Luther, still a monastic, biblical humanist, belonged with them, as he was capable of "using the linguistic, rhetorical and hermeneutical achievements of humanism". ${ }^{159}$ In turn, thanks to these humanists, Friar Luther's cause became the cause of the majority of Germans.

Yet the triumph of multilingual humanist theology in Erfurt was of short duration. Crotus's page may be nothing more than a "snapshot" that mirrors the temporary unity of the various humanists represented on it. Perhaps he had some presentiment of the disintegration of the humanist reform movement shortly afterwards and wanted to demonstrate humanist unity.

During the year 1521 strongly conservative forces elected a new university rector from their ranks. ${ }^{160}$ Mutian at Gotha disassociated himself from Luther, to the disappointment of Hessus. Mutian had nothing to contribute any more anyway, "except enthusiasm for eloquence and classical literature."161 The local monastic humanist, Augustinian Friar Lang, was expelled from the faculty of theology at Erfurt. Most of the others left the city altogether. With the departure of the monastic and the non-monastic humanists, the "brilliant star" of the University of Erfurt soon darkened, as the university sank into oblivion in the course of the sixteenth century. ${ }^{162}$ Luther in 1539 blamed the archbishop of Mainz for this disastrous decline. 163 Lang had already left the Augustinian order in 1522, and Luther followed him in 1525.

Yet not all seventeen men represented on Crotus's page became Protestant, "Lutheran" reformers during the dawn of the confessionalization of German humanism. Only eight of them later declared themselves followers of Luther: Jonas, Melanchthon, Lang, Draco, Crato, Camerarius, Menius, and Hutten. Crotus himself left Erfurt for Fulda and after 1530 worked at Halle for Cardinal Albrecht of Brandenburg, the Primas Germaniae. 164 Crotus thus distanced himself from Luther and his movement and returned to the Catholic camp. ${ }^{165}$ The polarization and confessionalization of humanism were in full swing. In 1533, Luther suspected that the former rector of Erfurt had "spit his poison" into the "booklet of lies" that the humanist priest Georg Witzel (Agricola Phagus [1501-73]) published against him concerning good works. Luther came to despise Crotus so strongly that he denigrated him as "the plate-licker of the Cardinal of Mainz" and derogatorily alluded to his name, which sounds like Kröte (toad) in German, calling him "Dr. Toad". 166 
All in all, this colorful parchment page demonstrates that monastic and non-monastic humanists worked together and that Friar Luther was one of them. Yet, this page contains much more than Luther. It shows his intellectual and cultural context, his milieu and matrix, the interconnectedness of "humanism," "monasticism" and "Reformation."

Beaver Dam, Wisconsin (Independent Scholar)

\section{Notes}

1. I am grateful to Professor Eckhard Bernstein for providing me with the reproduction of Crotus's Page, and to Stadtarchivdirektor Dr. Benl, Erfurt, for permission to reproduce it, and to Professor Richard Hillman for valuable editorial assistance.

2. Bernd Moeller, Imperial Cities and the Reformation: Three Essays, ed. and trans. H. C. Erik Midelfort and Mark U. Edwards, Jr., orig. title Reichsstadt und Reformation (1972; rpt. Durham, NC: Labyrinth Press, 1982), pp. 19-38 (citation p. 36). See also Erika Rummel, The Humanist-Scholastic Debate in the Renaissance and Reformation (Cambridge, MA: Harvard University Press, 1995), p. 130; Leif Grane, Martinus Noster: Luther in the German Reform Movement 1518-1521 (Mainz: P. von Zabern, 1994), p. 290; and Timothy P. Dost, Renaissance Humanism in Support of the Gospel in Luther's Early Correspondence: Taking All Things Captive (Aldershot, Hants: Ashgate, 2001), p. 212.

3. "Ohne Mönchtum keine Reformation" (Johannes Schilling, Klöster und Mönche in der hessischen Reformation [Gütersloh: Güterloher Verlagshaus, 1997], p. 11).

4. See Eckhard Bernstein, "Der Erfurter Humanistenkreis am Schnittpunkt von Humanismus und Reformation. Das Rektoratsblatt des Crotus Rubianus," in Der polnische Humanismus und die europäischen Sodalitäten. Pirckheimer Jahrbuch für Renaissance- und Humanismusforschung, 12 (Wiesbaden: Harrasowitz, 1997), p. 137.

5. See, notably, Lewis W. Spitz, Luther and German Humanism (Aldershot, Hants: Variorum, 1996).

6. Dost, p. 22.

7. See Helmar Junghans, Der junge Luther und die Humanisten (Göttingen: Vandenhoeck \& Ruprecht, 1985), which contains studies published in 1970 and later.

8. See Grane, p. 147-229, and his statement: "It is not Luther and the humanists, but rather Luther in the reform movement, that is the subject of this study" (p. 4).

9. See Brian Cummings, The Literary Culture of the Reformation: Grammar and Grace (Oxford: Oxford University Press, 2002), p. 7.

10. See Johannes Helmrath, "Theorie und Praxis der Kirchenreform im Spätmittelalter," Rottenburger Jahrbuch für Kirchengeschichte 11 (1992): 48. On the history of the notion of "reform," see Konrad Repken, "Reform," in Hans J. Hillerbrand, ed., The Oxford Encyclopedia of the Reformation, 4 vols. (New York: Oxford University Press, 1996), 3: 392-95.

11. Paul Oskar Kristeller, Renaissance Thought: The Classic, Scholastic, and Humanistic Strains (New York: Harper and Row, 1961), p. 79.

12. Rummel, The Humanist-Scholastic Debate, p. 2. 
13. On Graeca veritas and Hebraica veritas, see Nigel Guy Wilson, From Byzantium to Italy: Greek Studies in the Italian Renaissance (London: Duckworth, 1992), pp. 72-73, 131, 174 and n. 16.

14. See, e.g., Franz Posset, “'Rock' and 'Recognition': Martin Luther's Catholic Interpretation of 'You are Peter and on this rock I will build my Church' (Matthew 16:18) and the Friendly Criticism from the Point of View of the 'Hebrew Truth' by his Confrère, Caspar Amman, 'Doctor of the Sacred Page,'” in Timothy Maschke, Franz Posset, and Joan Skocir, eds., Ad fontes Lutheri: Toward the recovery of the real Luther: Essays in Honor of Kenneth Hagen's Sixty-fifth Birthday (Milwaukee, WI: Marquette University Press, 2001), pp. 214-46.

15. Cummings, p. 5.

16. Ibid., pp. 30-38.

17. In the dedication to his Resolutions of 30 May 1518, Luther explained the Latin poenitentia again with reference to the Greek $\mu \in \tau \alpha \dot{\alpha} v o l \alpha$; see D. Martin Luthers Werke, Weimarer Ausgabe (Weimar: H. Böhlau, 1883- ), 1: 525, lines 24-25. (This edition will henceforth be abbreviated as $W A$, with $W A B r$ referring to the volumes of Luther's correspondence.)

18. I apply this notion to Luther (and to his friend, Johannes Lang) in the friary. On Klosterhumanismus, see I. W. Nagl and Jakob Zeidler, Deutsch-Österreichische Literaturgeschichte, 4 vols. (Vienna and Leipzig: Carl Fromme, 1899), 1: 455; Richard Newald, "Beiträge zur Geschichte des Humanismus in Oberösterreich," Jahrbuch des oberösterreichischen Musealvereins 81 (1926): 155-223; Paul Richter, "Die Schriftsteller der Benediktinerabtei Maria-Laach, mit Textbeilagen. III: Die humanistische Epoche in Maria-Laach mit Rücksicht auf den rheinischen Klosterhumanismus überhaupt," Westdeutsche Zeitschrift für Geschichte und Kunst 17 (1912): 277-340; Franz Machilek, "Klosterhumanismus in Nürnberg um 1500," in Mitteilungen des Vereins für Geschichte der Stadt Nürnberg 64 (1977): 10-45; Rolf Schmidt, Reichenau und St. Gallen: ihre literarische Überlieferung zur Zeit des Klosterhumanismus in St. Ulrich und Afra zu Augsburg um 1500 (Sigmaringen: Thorbecke, 1985); and Harald Müller and Anne-Katrin Ziesak, "Der Augsburger Benediktiner Veit Bild und der Humanismus. Eine Projektskizze," Zeitschrift des historischen Vereins für Schwaben 95 (2002): 27-51, esp. 28-38. In English, the expression Monastic Humanism has come into use, as with Noel L. Brann, Abbot Trithemius (1462-1516): The Renaissance of Monastic Humanism (Leiden: Brill, 1981).

19. See Cummings, p. 124.

20. See Letter 464 in Helga Scheible and Dieter Wuttke, eds., Willibald Pirckheimers Briefwechsel, vols. 3-5 (Munich: Beck, 1989-2001), 3: 162, lines 549-80.

21. Ibid., 3: 163, lines 586-606; see also Grane, p. 18.

22. On Cuno, see Henri D. Saffrey, "Un humaniste dominicain, Jean Cuno de Nuremberg, précursor d'Érasme à Bâle," Bibliothèque d'Humanisme et Renaissance 33 (1971): 19-62, and Martin Sicherl, Johannes Cuno: Ein Wegbereiter des Griechischen in Deutschland: Eine biographisch-kodikologische Studie (Heidelberg: Winter, 1978); on Chelidonius, see Manfred Knedlik, "Chelidonius," in Friedrich Wilhelm Bautz, ed., Biographisch-Bibliographisches Kirchenlexikon, vol. 20 (Nordhausen: Bautz, 2002), pp. 293-96 (hereafter BBKL), and Franz Posset, "Benedictus Chelidonius O.S.B. (c.1460-1521), A Forgotten Monastic Humanist of the Renaissance," The American Benedictine Review 53 (2002): 426-52.

23. On Leyb as a Hebrew expert, see J.-M. and H. H. Keller, "Kilian Leib als Hebraist," Bibliotheksforum Bayern 22 (1994): 193-203. 
26 / Renaissance and Reformation / Renaissance et Réforme

24. On Staupitz, see Franz Posset, The Front-Runner of the Catholic Reformation: The Life and Works of Johann von Staupitz (Aldershot, Hants: Ashgate, 2003).

25. See Wilhelm Reindell, ed., Wenzel Lincks Werke gesammelt und herausgegeben mit Einleitungen und Anmerkungen (Marburg: Oscar Ehrhardt, 1894).

26. See Günter Vogler, "Erwartung — Enttäuschung — Befriedigung: Reformatorischer Umbruch in der Reichsstadt Nürnberg," in Stephen E. Buckwalter and Bernd Moeller, eds., Die frühe Reformation in Deutschland als Umbruch (Gütersloh: Gütersloher Verlag, 1998), pp. 393 and 400. Friar Volprecht was the prior of the Nuremberg Augustinians at about the time when Crotus designed his page; Volprecht was the last prior, and he handed over the entire friary to the city government; see Posset, FrontRunner, pp. 21 and 280.

27. See Posset, Front-Runner, p. 163.

28. Felix published a fresh translation of the Psalter from Hebrew into Latin: Psalterium ex Hebraeo ad verbum fere translatum (Venice 1515), which Luther used; see Posset, "'Rock' and 'Recognition,"” p. 237.

29. See Willigis Eckermann, “Amman (Ammon)," in Klaus Ganzer and Bruno Steimer, eds., Lexikon der Reformationszeit (Freiburg: Herder, 2002), p. 27 (hereafter LR), and Franz Posset, "Amman," in BBKL, vol. 16 (1999), pp. 49-52. Amman translated the Psalter from Hebrew into German in 1523.

30. Hebraei fontem, Graeci rivulos, Latini paludem bibunt; see Posset, “'Rock' and 'Recognition,"” p. 235.

31. Franciscus Irenicus, Germaniae exegeseos volumina duodecim (Hagenau and Nuremberg, 1518), fol. 44 ${ }^{\mathrm{v}}$. The title-page is reproduced in Stefan Rhein, Armin Schlechter and Udo Wennemuth, eds., Philipp Melanchthon in Südwestdeutschland: Bildungsstationen eines Reformators (Karlsruhe 1997), p. 244; Junghans, Der junge Luther, p. 295; and Posset, Front-Runner, pp. 199-200.

32. See Junghans, Der junge Luther, p. 288.

33. See P. Becker, "Benediktinische Reformbewegungen und klösterliches Bildungsstreben," Rottenburger Jahrbuch für Kirchengeschichte 11 (1992): 170.

34. See Franz Posset, "Frater Augustinus (Martin Luther) in Erfurt und seine Lektüre geistlicher Autoren, insbesondere Bernhards," Luther-Bulletin 11 (2002): 44-45.

35. See Müller and Ziesak; also Franz Posset, "The Benedictine Humanist Vitus Bild (1481-1529): Sundial Producer, Mathematician, Linguist, Poet, Historiographer, Music Expert, Pro-Lutheran, Anti-Zwinglian," The American Benedictine Review (forthcoming, 2004).

36. See Franz Posset, "Leontorius," in BBKL, vol. 19 (2001), pp. 896-900, and "Leontorius," in Verfasserlexikon, Ergänzungsband Deutscher Humanismus 1480-1520 (forthcoming).

37. See Eckhard Bernstein, "From Outsiders to Insiders: Some Reflections on the Development of a Group Identity of the German Humanists between 1450 and 1530," in James V. Mehl, ed., In Laudem Caroli: Renaissance and Reformation Studies for Charles G. Nauert (Kirksville, MO: Thomas Jefferson University Press, 1998), pp. 45-64.

38. See Junghans, Der junge Luther, p. 34.

39. See Ferdinand Geldner, Die deutschen Inkunabeldrucker: Ein Handbuch der deutschen Buchdrucker des XV. Jahrhunderts nach Druckorten, 2 vols., vol. 1: Das Deutsche Sprachgebiet (Stuttgart: Hiersemann, 1968-70), p. 207, fig. 87. 
40. See David Werner Amram, The Makers of Hebrew Books in Italy: Being Chapters in the History of the Hebrew Printing Press (1909; rpt. London: Holland Press, 1963).

41. See Friedrich Kaiser, Reformations-Almanach 1817, pp. $81 \mathrm{ff}$,, as referred to by August Emil Frey, Luther und seine Freunde. Erster Theil. Die Freunde Luthers bis zum Beginne der Reformation (Saint Louis, MO: Concordia, 1884), p. 66. Crotus's table of emblems is depicted in Ernest G. Schwiebert, Luther and His Times: The Reformation from a New Perspective (Saint Louis, MO: Concordia, 1950), plate 40.

42. See Erika Rummel, The Case against Johann Reuchlin: Religious and Social Controversy in Sixteenth-Century Germany (Toronto: University of Toronto Press, 2002), p. 23.

43. 16 October 1519, see WABr, 1: 540-44; see Grane, p. 195.

44. At times this shield is still assigned, though incorrectly, to Urbanus Rhegius, as by Martin Lehmann, Justus Jonas: Loyal Reformer (Minneapolis, MI: Augsburg Publishing House, 1963), p. 27.

45. See Frey, p. 67.

46. His Latinized first name is rarely used, as it is, for example, in one of Mutianus' letters (year 1505); see Carl Krause, Der Briefwechsel des Mutianus Rufus (Kassel: A. Freyschmidt, 1885), p. 8 (letter 8). Usually he is addressed as H. Urbanus. On him, see Franz Posset, "A Cistercian Monk as Editor of the Carmen of the Croatian Humanist Marcus Marulus (died 1524): The German Humanist Henricus Urbanus O. Cist (died ca. 1538)," Cistercian Studies Quarterly (forthcoming, 2004).

47. See Frey, p. 67. Bernstein, however, believes ("Der Erfurter Humanistenkreis," p. 153) that the abbreviations stand for the German words Christus mein Trost ("Christ [is] my comfort"), as appears doubtful, considering that Urbanus was a skilled Latinist.

48. Vale, mi Urbane, amicorum optime, maxime, Krause, ed., p. 65 (letter 60 of spring 1506).

49. Rotae dimidium does not mean "half a wheel," as assumed by Krause, p. 261, and Ingeborg Gräßer-Eberbach, Helius Eobanus Hessus: Der Poet des Erfurter Humanistenkreises (Erfurt: Verlagshaus Thüringen, 1993), p. 25.

50. See Letter of 11 November 1512 (Krause, ed., p. 262 [letter 207]).

51. His first publication dates from 1524 , i.e., several years after his inclusion on the rector's page. See Frank Baron, ed., Joachim Camerarius (1500-1574): Beiträge zur Geschichte des Humanismus im Zeitalter der Reformation (Munich: W. Fink, 1978), p. 233.

52. See Henry de Vocht, History of the Foundation and the Rise of the Collegium Trilingue Lovanense 1517-50, 4 vols. (Louvain: Bibliothèque de l'Université, Bureaux du Recueil, 1953).

53. See Thomas Haye, "Marschalk," in LR, pp. 498-99, and Helmar Junghans, "Das bleibende Erbe des Humanismus in der Reformatorischen Bewegung," in Ulrich Gäbler and Endre Zsindely, eds., Bullinger-Tagung 1975: Vorträge, gehalten aus Anlass von Heinrich Bullingers 400. Todestag (Zurich: Instituts für Schweizerische Reformationsgeschichte, 1977), p. 130; Maria Grossmann, Humanism in Wittenberg 1485-1517 (Nieuwkoop: De Graaf, 1975), p. 47; R. W. Scribner, "The Erasmians and the Beginning of the Reformation in Erfurt," The Journal of Religious History 9 (1976/77): 7-8; and Dieter Stievermann, "Marschalk (c.1470-1525), Spalatin (1484-1545), Mutian (c.1470-1526), Hessus (1488-1540) und die Erfurter Humanisten," in Dietmar von der Pfordten, ed., Große Denker Erfurts und der Erfurter Universität (Göttingen: Wallstein Verlag, 2002), pp. 118-42. 
28 / Renaissance and Reformation / Renaissance et Réforme

54. See Junghans, “Das bleibende Erbe,” p. 130.

55. Neither Marschalk nor Trebelius nor Spalatin is represented on Crotus's page.

56. Under this line one reads in brown ink: "Joannes crotus [sic] Theologiae professor."

57. The original spelling has partially capital Greek letters and $\sigma$ instead of $\varsigma$ at the end of a word.

58. See Bernstein, "Der Erfurter Humanistenkreis," p. 158.

59. Ibid., p. 140.

60. See Scribner, p. 3.

61. See Josef Pilvousek, "Martin Luther und Erfurt," in Josef Freitag, ed., Luther in Erfurt und die katholische Theologie (Leipzig: Benno Verlag, 2001), p. 21.

62. The capitalizations were made by Crotus. See Scribner, p. 28.

63. Grane, p. 286

64. For the transcription of the original Latin and for a German translation, see Bernstein, "Der Erfurter Humanistenkreis," pp. 139 and 151, n. 39.

65. See Schwiebert, p. 133.

66. See $W A B r, 5$ : 445, lines 1-12 (no. 1628). The earliest print (woodcut) of a portrait of Luther and the Luther Rose is found with the title page of Luther's sermon delivered at Leipzig on the feast day of Saints Peter and Paul, 1519 (during the Leipzig Disputation), as printed by Wolfgang Stöckel. This Luther Rose (1519) does not include any cross at the center at all. Perhaps Crotus picked the seal for Luther from this title page and added the papal cross.

67. See Helmar Junghans, "Der nationale Humanismus bei Ulrich von Hutten und Martin Luther," in Michael Beyer and Günther Wartenberg, eds., Spätmittelalter, Luthers Reformation, Kirche in Sachsen Ausgewählte Aufsätze (Leipzig: Evangelische Verlagsanstalt, 2001), pp. 67-90.

68. See Kurt Stadtwald, Roman Popes and German Patriots: Antipapalism in the Politics of the German Humanist Movement from Gregor Heimburg to Martin Luther (Geneva: Droz, 1996).

69. See Dieter Mertens, "Nation als Teilhabeverheißung: Reformation und Bauernkrieg," in Dieter Langewiesche and Georg Schmidt, eds., Föderative Nation. Deutschlandkonzepte von der Reformation bis zum Ersten Weltkrieg (Munich: R. Oldenbourg, 2000), pp. 115-34.

70. As displayed by the Dominican historiographer Felix Fabri (died 1502), who wrote on the Suevia natio (the "Swabian tribe/nation"); see also Klaus Graf, "Reich und Land in der südwestdeutschen Historiographie um 1500," in Franz Brendle, Dieter Mertens, Anton Schilling, and Walter Ziegler, eds., Deutsche Landesgeschichtsschreibung im Zeichen des Humanismus (Stuttgart: F. Steiner, 2001), p. 207.

71. See Friedrich Wilhelm Bautz, "Hessus," in BBKL, vol. 2 (1990), pp. 791-93, and Walther Ludwig, "Eobanus Hessus in Erfurt. Ein Beitrag zum Verhältnis von Humanismus und Protestantismus," Mittellateinisches Jahrbuch 33 (1998): 155-71.

72. See Gräßer-Eberbach, pp. 62-63, and Bernstein, “Der Erfurter Humanistenkreis,” p. 144.

73. See Junghans, "Der nationale Humanismus," p. 84.

74. In Psalmum CXVIII (Nuremberg: [n.pub.], 1530); WA, 31-I: $43-48$ (six printed pages). 
75. See $W A B r, 5:$ 201-3; Luther asked Hessus for a Latin poem on Psalm 118. Hessus complied; see Gräßer-Eberbach, pp. 120-21, and Gerlinde Huber-Rebenich, "Der lateinische Psalter des Eobanus Hessus und das Ideal der docta pietas," in Die Musen im Reformationszeitalter, ed. Walther Ludwig (Leipzig: Evangelische Verlagsanstalt, 2001), pp. 289-303.

76. In Evangelici Doctoris M. Lutheri laudem defensionemque elegiae (1521); see Scribner, p. 28, and Friedrich Wilhelm Bautz, "Hessus," in BBKL, vol. 2 (1990), pp. 791-93.

77. See the Latin original and German version of the first elegy in Gräßer-Eberbach, p. 97.

78. Ibid., p. 98 ("Pro te Germania stabit in armis"); see also following note.

79. Hessus evidently tried, using his literary skill, to create a united front of humanists who sided with the Reformer in his Luther Elegies: Helii Eobani Hessi in Martinum Lutherum Elegiarum libellus, de eius in urbem Erphurdiam ingressu, Elegia prima. De Ingressu Lutheri in Urbem Erphurdiam Elegia Secunda. De Contione Lutheri ad Populum Erphurdiensem honoribusque eidem exhibitis. Ad Martinum Erphurdia abeuntem, Elegia Quarta. Ad Iustum Ionam Theologum cum Martino redeuntem a Caesare, Elegia V. Ad Hulderichum Huttenum Equitem ac Poetam, ut Lutheri causam adserat, Elegia VI. Luther and Hutten are placed in close proximity because it was obvious around 1520 that Hutten's Vadiscus and Luther's To the Christian Nobility share the same ideas and use the same source material; see Heinrich Dannenbauer, Luther als religiöser Volksschriftsteller 1517-1520. Ein Beitrag zu der Frage nach den Ursachen der Reformation (Tübingen: J. C. B. Mohr, 1930), p. 4.

80. Lehmann, p. 13.

81. See Cornelis Augustijn, Erasmus von Rotterdam: Leben, Werk, Wirkung (Munich: Beck, 1986), p. 165; on Hutten, see Hajo Holborn, Ulrich von Hutten and the German Reformation, trans. Roland Bainton (New Haven, CT: Yale University Press, 1937).

82. See WABr, 1: 122, line 56 (no. 52). Twenty-eight letters of Luther show Eleutherius as his self-designation; see Bernd Moeller and Karl Stackmann, Luder - Luther Eleutherius: Erwägungen zu Luthers Namen (Göttingen: Vandenhoeck \& Ruprecht, 1981), p. 8.

83. He had written to the theology faculty at Erfurt in December 1514: Mater mea Erfordiensis Universitas, WABr, 1: 30, lines 37-38; see Jun Matsuura, "Luther als Dozent an der Erfurter Universität. Auf den Spuren seiner Anfänge," in Roswitha Jacobsen, ed., Erfurter Universitätslesungen (Erfurt, 1992), p. 47, and Pilvousek, p. 13.

84. Theologia Teütsch. Das ist ain edels vnd kostlichs büchlin, von rechtem verstannd, was Adam vnd Christus sey (Augsburg: Siluanus Otmar, 1518); The Theologia Germanica of Martin Luther, trans. and ed. Bengt Hofman (New York: Paulist Press, 1980), p. 54.

85. See WA, 56: 472, line 10; see Junghans, "Der nationale Humanismus," p. 84.

86. See Scribner, p. 20, and Bernstein, “Der Erfurter Humanistenkreis,” p. 161.

87. See Sam Wheelis, "Ulrich von Hutten: Representative of Patriotic Humanism," in Gerhart Hoffmeister, ed., The Renaissance and Reformation in Germany: An Introduction (New York: F. Ungar, 1977), pp. 111-27.

88. See Hutten, Epistolae obscurorum virorum, in Operum supplementum, as cited by Junghans, "Der nationale Humanismus," p. 77.

89. See Junghans, "Der nationale Humanismus,” p. 82. 
30 / Renaissance and Reformation / Renaissance et Réforme

90. See Bernstein, "Der Erfurter Humanistenkreis," pp. 145-46. Note that Luther dedicated his book on individual confession to Franz von Sickingen; see $W A B r, 2: 337$, lines 33-34.

91. See Junghans, "Der nationale Humanismus," p. 81.

92. Erasmus to Jonas, 10 May 1521, in P. S. Allen, ed., Opus epistolarum Des. Erasmi Roterdami, 14 vols., vol. 4 (Oxford: Clarendon Press, 1923), p. 487 (no. 1202).

93. See Bk. IV, III.6, in Sancti Bernardi Opera, ed. Jean Leclercq, C. H. Talbot, and Henri Rochais, vol. 3 (Rome: Editiones Cistercienses, 1963), pp. 453-54.

94. See Lehmann, pp. 2-3, and Erich Kleineidam, "Die Bedeutung der Augustinereremiten für die Universität Erfurt im Mittelalter und in der Reformationszeit," in Cornelius Petrus Mayer and Willigis Eckermann, eds., Scientia Augustiniana. Studien über Augustinus, den Augustinismus und den Augustinerorden. Festschrift P. Dr. theol. Dr. phil. Adolar Zumkeller OSA zum 60. Geburtstag (Würzburg: AugustinusVerlag, 1975), p. 411.

95. See Scribner, p. 28.

96. See Lehmann, pp. 27-28, and Hans-Günter Leder, “Jonas," in LR, pp. 374-75.

97. Lehmann, pp. 27-28.

98. On Jonas's work as a translator, see Otto Clemen, Unbekannte Drucke, Briefe und Akten aus der Reformationszeit (Leipzig: O. Harrassowitz, 1942; fac. rpt. Wiesbaden: [n.pub.], 1968), and Lehmann, pp. 184-86.

99. See Lehmann, p. 185.

100. Antilatomus, WA, 8: 43-128.

101. See Roland H. Bainton, Erasmus of Christendom (New York: Crossroad, 1982), pp. 105-9.

102. "Pestis christianismi" (Allen, ed., vol. 3 [1913], p. 408 [no. 872]); see also Bernstein, "Der Erfurter Humanistenkreis," p. 160.

103. See Bainton, p. 130. On Erasmus the Netherlander, see Istvan Bejczy, "Erasmus becomes a Netherlander," Sixteenth Century Journal 28 (1997): 387-99.

104. See Bainton, p. 227.

105. Grane, p. 202.

106. Scribner, p. 28.

107. See Scribner, p. 25, and Bernstein, "Der Erfurter Humanistenkreis," p. 146.

108. See Stephan Kunkler, Zwischen Humanismus und Reformation: Der Humanist Joachim Camerarius (1500-1575) im Wechselspiel von pädagogischem Pathos und theologischeem Ethos (Hildesheim: Olms, 2000), p. 33.

109. See Quae hoc libello habentur. Divi Hieronymi epistola ad magnum urbis oratorem elegantissima. Eiusdem ad Athletam de filiae educatione. F. Philelphi epistola de Hieronymo et Augustino (Wittenberg: Grunenberg, 1515).

110. See Reinhold Weijenborg, "Die Wittenberger Römerbriefvorlesung des Erfurter Augustiners Johannes Lang: Erstausgabe nach dem Vat. Pal. Lat. 132 mit Einleitung und Kommentar," Antonianum 51 (1976): 394-494.

111. See Reinhold Weijenborg, "Die Wittenberger Titusbriefvorlesung des Erfurter Augustiners Johannes Lang nach dem Vat. Pal. Lat. 132 mit Einleitung und Kommentar," in Mayer and Eckermann, Scientia, pp. 423-68. 
112. See Scribner, p. 15.

113. See Luther to Lang, 29 May 1522, WA, 9: 115; WABr, 2: 547, lines 2 ff.

114. Das heilige Euangelium Matthei aus Kriechsersprach /vn bisweilen aus des hochgelerte hern Erasmi vo Roterdam translacion durch den wirdigen doctore Johane Langeiu vo[n] Erffurt Augustiner ordens yns deutsch gebracht / wilches tzu gotlicher ere beschirmug der warheit/vn de warhafftige christen/nutz vnd selicheit yres lebens tzu besserung geschehen ist. Ano M.D. xxi. (1521); see F. Brossmann, Die Matthäusübersetzung von Johannes Lange im Jahre 1521 (Unpublished Dissertation, Heidelberg, 1955), and Brigitte Döring, "Zur Übersetzung des Matthäus-Evangeliums durch den Erfurter Reformator Johannes Lang," Mitteldeutsches Jahrbuch für Kultur und Geschichte 6 (1999): 43-53.

115. See Stefan Rhein, "Lang," in Walter Killy, ed., Literaturlexikon. Autoren und Werke deutscher Sprache, 15 vols. (Munich: Bertelsmann Lexikon Verlag, 1990), 7: 134-35.

116. "Petrus Aperbachus, Li[terariae] dis[ciplinae] d[doctor]" is his self-designation in his letter to Johannes Lang of 5 September 1508, in Martin Burgdorf, ed., Der Einflu $\beta$ der Erfurter Humanisten auf Luthers Entwicklung bis 1510 (Leipzig: [n. pub.], [n. d.], [c.1925]), pp. 124-25.

117. See Wilhelm Kühlmann, "Eberbach," in Killy, ed., Literaturlexikon, 3: 139-40, and Bernstein, "Der Erfurter Humanistenkreis," pp. 147-49.

118. See Burgdorf, p. 41.

119. Also simply called Karlstadt; but he must not be confused with Andreas Bodenstein von Karlstadt, professor at Wittenberg and a later radical reformer.

120. See Krause, p. 8 (letter 8).

121. Letter of the year 1505 (Krause, ed., p. 36 [letter 20]).

122. "Et prodesse studet latinitati" (Krause, ed., p. 1 [letter 1]).

123. See Kleineidam, "Die Bedeutung der Augustinereremiten," p. 414.

124. See Bernstein, "Der Erfurter Humanistenkreis," pp. 147-48.

125. See Kleineidam, "Die Bedeutung der Augustinereremiten,” p. 406.

126. Ibid., p. 414.

127. See Bernstein, "Der Erfurter Humanistenkreis," p. 148.

128. See Scribner, p. 27, and Kunkler, p. 40.

129. See Friedrich Wilhelm Bautz, "Draconites (Drach)," in $B B K L$, vol. 1 (1990), pp. 1374-76, and Robert Stupperich, Reformatorenlexikon (Gütersloh: Gütersloher Verlagshaus G. Mohn, 1984), pp. 69-70.

130. See Werner Schwarz, Principles and Problems of Biblical Translation: Some Reformation Controversies and Their Background (Cambridge: Cambridge University Press, 1955), p. 68.

131. See $W A, 1: 158$.

132. See $W A, 9: 24$ and $34 \mathrm{ff}$. (on De civitate dei).

133. WA, 9: 32, line 9 (Lombardus, Liber I, dist. 2, c. 6); see Franz Posset, "Frater Augustinus (Martin Luther) in Erfurt und seine Lektüre geistlicher Autoren, insbesondere Bernhards," Luther-Bulletin 11 (2002): 33.

134. See WA, 9: 25-32, 63-67. On Augustine's De civitate dei, see WA, 9: 25, lines 38-39, and 26, lines 2-5 and 11-13, as well as Siegfried Raeder, Das Hebräische bei Luther 
32 / Renaissance and Reformation / Renaissance et Réforme

untersucht bis zum Ende der ersten Psalmenvorlesung (Tübingen: J. C. B. Mohr, 1961), pp. 62-63, 184-85. See also Junghans, Der junge Luther, p. 181.

135. See WA, 9: 66, lines 11-14.

136. See Martin Luther, Annotierungen zu den Werken des Hieronymus, ed. Martin Brecht and Christian Peters (Cologne: Böhlau, 2000).

137. "Gratulor misericordiae Dei, quae in te est [. . .].Fuisti tu sane organum consilii divini, sicut tibi ipsi incognitum, ita omnibus pura theologiae studiosis expectatissimum [. . .].Vale et gaude in Domino, praeceptor vere mihi venerabilis" WABr, 1:268-69 (no. 120).

138. Sigs. $\mathrm{C}^{\mathrm{v}}$ and $\mathrm{C} 4^{\mathrm{r}}$; see Hans Peterse, "Die Dominikaner und die Causa Reuchlini (1510-1520)," in Reinhold Mokrosch and Helmut Merkel, eds., Humanismus und Reformation. Historische, theologische und pädagogische Beiträge zu deren Wechselwirkung (Münster: Lit Verlag, 2001), p. 55.

139. "Invadunt dentes istius Behemoth me, si quo modo sarcire queant ignominiam, quam retulerunt ex te" (WABr, 1: 268, lines 10-11); the translation furnished is my own). Luther used Behemoth again in the preface to the Acta Augustana (1518) (WA, 2:6, line 16).

140. See Raeder.

141. See $W A, 1: 219$, line 14 .

142. On Camerarius, see Baron, and Kunkler, p. 29; the following students were members of the sodality of Eobanus: Adam Crato, Justus Jonas, Justus Menius, Johannes Lang, Johannes Draco; but also Daniel Stibarius (1503-55), Euricius Cordus (alias Heinrich Solde, 1484-1535), and Crotus. One wonders why Cordus and Stibarius are not included on Crotus's page.

143. See Kleineidam, "Die Bedeutung der Augustinereremiten," p. 412, and Kunkler.

144. See Bernstein, "Der Erfurter Humanistenkreis," p. 149.

145. See Stupperich, pp. 143-44; Michael Becht, "Menius," in $L R$, p. 509.

146. See Erika Rummel, The Confessionalization of Humanism in Reformation Germany (Oxford: Oxford University Press, 2000), pp. 103-4.

147. "Wider den hochberühmten Barfüßer Doktor Konrad Kling Schutzred und gründliche Erklärung etlicher Hauptartikel christlicher Lehre" (WA 23, p. 16, lines 2-5); see Erich Kleineidam, Universitas Studii Erffordensis: Überblick über die Geschichte der Universität Erfurt im Mittelalter 1392-1521, Teil II: 1460-1521, 2nd ed. (Leipzig: St. Benno-Verlag, 1992), p. 90.

148. Originally from Fulda; later the reformer of Hessen; see Walter Schäfer, Adam Krafft: Landgräfliche Ordnung und bischöfliches Amt (Kassel: [n.pub.], 1976). There is another Adam Krafft, who was a sculptor at Nuremberg, but who died in 1509.

149. See Stupperich, pp. 122-23, Gerhard Müller, "Krafft (Crato)," in LR, p. 412.

150. See Kunkler, p. 30.

151. Ibid., p. 37.

152. Ibid., pp. 41 and 55.

153. See Kleineidam, Universitas Studii Erffordensis, vol. 2, p. 183, where Erasmus, Reuchlin, and Mutianus are declared the three "große deutsche Humanisten." Evidently, Crotus on his page had added Luther as the fourth. 
154. Grane, p. 204. To speak of a deeply rooted alliance of "Reuchlin-Erasmus-Luther" (Grane, p. 266) may be overstating the situation.

155. Apotheosis Capnionis: De incomparabili heroe Joanne Reuchlin in divorum numerum relato, in Colloquia, ed. L. E. Halkin, F. Bierlaire, and R. Hoven, Opera omnia, ser. 1, vol. 3 (Amsterdam: North-Holland Publishing, 1972), pp. 267-73. See Anna Morisi, "Traditionalism, Humanism, and Mystical Experience in Northern Europe and in the Germanic Areas in the Fifteenth and Sixteenth Centuries," in Giulio D'Onofrio, ed., History of Theology III: The Renaissance (Collegeville, MN: The Liturgical Press, 1996), p. 351.

156. See Posset, Front-Runner, pp. 201-2.

157. Grane, p. 201.

158. See Bernstein, "Der Erfurter Humanistenkreis,” p. 150.

159. Grane, p. 290.

160. See Scribner, p. 29; Bernstein, "Der Erfurter Humanistenkreis," pp. 159 and 164; and Grane, p. 283.

161. Grane, p. 283.

162. See Bernstein, "Der Erfurter Humanistenkreis," p. 164.

163. See Pilvousek, p. 14.

164. On Albrecht and Luther, see Bernhard Lohse, "Albrecht von Brandenburg und Luther," in Friedhelm Jürgensmeier, ed., Erzbischof Albrecht von Brandenburg (1490-1545): Ein Kirchen- und Reichsfürst der Frühen Neuzeit (Frankfurt: Josef Knecht, 1990), pp. 73-83.

165. See Rummel, Confessionalization, p. 77.

166. "Des Cardinals zu Mentz [Mainz] Tellerlecker, Dotter [Doctor] Kroete genant, sol seiner gift viel jnn dos buechlin gespeiet haben" (WA, 38: 12-13). The "booklet of lies" by Georg Witzel (alias Agricola Phagus) is refuted in the printed response of the pastor of Hirsfeld, Balthasar Raid(a) (c.1495-1565), with a Preface by Luther: Widder das lester vnd lügen büchlin Agricole Phagj, genant Georg Witzel. Antwort / Balthassar Raida pfarherr zu Hirsfeld [Hersfeld]; Vorrede D. Martinj Lutherj. Wittemberg. M D XXXIII. Witzel's work was Coacervatio [the heaping] locorum utriusque testamenti de absoluta necessitate bonorum fide operorum (Leipzig 1532; Cologne 1548), or, Pro defensione bonorum operum, adversus novos evangelistas. Auctore Agricola Phago (Leipzig: Michael Blum, 1532). 